\title{
Consumption of the bark of Albizia niopoides (Mimosaceae) by Sapajus cay Illiger, 1815 (Cebidae: Primates) in the Atlantic Forest fragment of Rancho Laguna Blanca in Eastern Paraguay
}

\author{
Rebecca L. Smith \\ Carter J. Payne \\ Fundación Para La Tierra, Rancho Laguna Blanca, Santa Rosa del Aguaray, San Pedro, Paraguay. \\ rebecca@paralatierra.org
}

Self-medication in animals, (zoopharmacognosy) is the process by which wild animals use specific plants to combat disease or parasitic infections (Huffman, 2003; Jain et al., 2008). Zoopharmacognosy has been most widely studied in the African great apes with well-known examples including Pan troglodytes, Gorilla gorilla and Pan paniscus ingesting and defecating whole leaves to purge intestinal parasites (Huffman et al., 1996; Huffman, 1997; Huffman \& Caton, 2001) and consuming potentially toxic plants with anti-parasitic properties (Clayton \& Wolfe, 1993; Masi et al., 2012). In neotropical primates, examples of self-medication include Ateles belzebuth and Alouatta seniculus consuming soil at mineral licks (Link et al., 2011) and fur-rubbing with noxious invertebrates and strong smelling plants in Cebus and Sapajus species (Weldon et al., 2003; Leca et al., 2007; Lynch Alfaro et al., 2011), Ateles geoffroyi (Laska et al., 2007) and Aotus spp. (Jefferson et al., 2014).

The majority of reports of self-medication in capuchins focus on fur-rubbing behaviours (Fragaszy et al., 2004; Paukner \& Suomi, 2012; Meuner et al., 2008). Here, we report on observations of Hooded Capuchins in Rancho Laguna Blanca (RLB), feeding on the bark of the tree Albizia niopoides (Mimosaceae), a possible case of self-medication.

Rancho Laguna Blanca (RLB) is an 804-ha reserve located in San Pedro, Paraguay ( $23^{\circ} 4952.0^{\prime \prime} \mathrm{S}$ and $56^{\circ} 17^{\prime} 42.2^{\prime \prime} \mathrm{W}$ ) in the Cerrado and Atlantic Forest ecoregions transitional zone. A 243-ha fragment of secondary Upper Paraná Atlantic Forest fragment, characterized by deciduous, mesophytic and broadleaf plants (Lowen et al., 1996), is located within the RLB, which is also home of to two groups of capuchins that have been observed since 2013. A study of the dietary diversity of the two groups (O and F) has been on-going since February 2016. Preliminary results show the capuchins consume at least 20 species of fruit, from 9 families, available throughout the year, as well as large amounts of bamboo, insects and agricultural crops (Smith et al., in prep). O Group consisted of 18 individuals ( 3 adult males, 5 adult females, 5 subadults, 4 juveniles and 1 infants) (Smith \& Briggs, 2015) in February 2016 and one infant was born during the study. F Group consists of around 16 individuals and the exact demographic structure of this group is yet to be confirmed. Scan samples (Altmann, 1974) at oneminute intervals were carried out and when feeding behaviour was observed the food item and processing technique recorded.

Bark eating behaviour was witnessed on multiple occasions throughout the year by individuals of all ages in both capuchin groups. All individuals used the same technique for processing A. niopoides sticks, and juveniles were observed exhibiting begging behaviour for sticks that were already being processed by adult monkeys (Figure 1). When removing the bark from sticks the capuchins held the stick in two hands, with one hand at either end or both hands together close of the end of the stick that is inserted into the mouth. The stick was chewed slightly and then the incisor teeth were used to peel the bark from the stick. The bark was then ingested while the stick was thrown to the ground. Individuals spent up to two minutes processing a single stick. On one occasion, an adult male capuchin was observed repeatedly hammering a stick into a tree branch before processing it and consuming the bark. Only the bark of A. niopoides was observed being eaten by the capuchins. 


\title{
Notas $\mid$ Notes
}

A. amara showed antiplatelets aggregation and antibacterial properties (Yadava \& Tripathi, 2000). Derivatives of Albizia julibrissin were found to have high antioxidant activity (Lau et al., 2007). Extracts of alkaloids isolated from the bark and leaves of Albizia adinocephala were found to inhibit a malarial enzyme (Ovenden et al., 2002). Albizia zygia has been found to have antimalarial properties (Abdalla \& Laatsch, 2012). This hypothesis that this behaviour is a form of self-medication needs to be tested by thorough phytochemical investigation of $A$. niopoides bark.

\section{Acknowledgements}

We thank all PLT volunteers and the Secretaria del Ambiente for their support of Fundación Para La Tierra.

\section{References}

ABDALLA, M.A \& H LAATSCH 2012. Flavonoids from Sudanese Albizia zygia (Legminosae, subfamily Mimosoideae), A Plant with Antimalarial Potency. African Journal of Traditional Complementary and Alternative Medicines 9: 56-58.

ALTMANN, J 1974. Observational Study of Behavior: Sampling Methods. Behaviour 49: 227-267.

ARCE, M.L.R 1992. Notes on Albizia niopoides (Spruce ex Benth.) Burkart (Leguminosae: Mimosoideae). Kew Bulletin 47: 699-702.

CLAYTON, D.H \& N.D WOLFE 1993. The Adaptive Significance of Self-Medication. TREE 8: 60-63.

FRAGASZY, D.M et al 2004. The Complete Capuchin: The Biology of the Genus Cebus. Cambridge University Press, Cambridge, UK. p $102-104$.

HUFFMAN, M.A 1997. Current Evidence for Self-Medication in Primates: A Multidisciplinary Perspective. Yearbook of Physical Anthropology 40:171200.

HUFFMAN, M.A 2003. Animal Self-Medication and Ethno-Medicine: Exploration and Exploitation of the Medicinal Properties of Plants. Proceedings of the Nutrition Society 62: 371-381.

HUFFMAN, M.A et al 1996. Leaf-Swallowing by Chimpanzees: A Behavioral Adapatation for the Control of Strongyle Nematode Infections. International Journal of Primatology 72: 475-503.

HUFFMAN, M.A \& J.M CATON 2001. Self-Induced Increase of Gut Motility and the Control of Parasitic Infections in Wild Chimpanzees. International Journal of Primatology 22: 329-346.

JAIN, C.P et al 2008 Animal Self-Medication through Natural Sources. Natural Product Radiance 7: 49-53.

JANGWAN, J.S 2010. New Cytotoxic Saponin of Albizia lebbeck. Indian J Chemists 49:123-126.

JEFFERSON, J.P 2014. Owl Monkeys (Aotus spp.) Perform Self- and Social Anointing in Captivity. Folia Primatologia 85: 119-134.

KOKILA, K et al 2013. Phytopharmacological Properties of Albizia Species: A Review. International Journal Pharmacy and Pharmaceutical Science 5: 7073.

LAU, C.S et al 2007. Identification and Quantification of Glycoside Flavonoids in the Energy Crop Albizia Julibrissin. Bioresour Technol 98: 429-435.

LASKA, M et al 2007. Self-Anointing Behaviour in Free-Ranging Spider Monkeys (Ateles geoffroyi) in Mexico. Primates 48: 160-163.

LECA, J.B et al 2007. Social Aspects of Fur-Rubbing in Cebus capucinus and C. apella. International Journal of Primatology 28: 801-817.

LINK, A et al 2011. Patterns of Mineral Lick Visitation by Spider Monkeys and Howler Monkeys in Amazonia: Are Licks Perceived as Risky Areas? American Journal of Primatology 73: 386-396.

LYNCH ALFARO, J.W et al 2011. Anointing Variation Across Wild Capuchin Populations: A Review of Material Preferences, Bout Frequency and Anointing Sociality in Cebus and Sapajus. American Journal of Primatology 7: 1-16.

OVENDEN, S.P 2002. Spermine Alkaloids from Albizia adinocephala with Activity Against Plasmodium falciparum Plasmepsin II. Phytochem. 60: 175177.

MASI, S et al 2012. Unusual Feeding Behavior in Wild Great Apes, a Window to Understand Origins of Self-Medication in Humans: Role of Sociality and Physiology on Learning Process. Physiology \& Behavior 105: 337-349.

MEUNER, H 2008. Social Facilitation of Fur Rubbing in White-Faced Capuchins. American Journal of Primatology 70: 161-168.

PARR N.A, L.M FEDIGAN, S.J KUTZ 2013. A Coprological Survey of Parasites in White-Faced Capuchins (Cebus capucinus) from Sector Santa Rosa, ACG, Costa Rica. Folia Primatologia 84:102-114

PAUKNER, A \& S.J SUOMI, 2012. Social After-Effects of Fur Rubbing in Tufted Capuchin Monkeys (Cebus apella): Increased Antagonism and Reduced Affiliation. Primates 53: 297-301.

PERRY, S \& J.H MANSON 2008. Manipulative Monkeys. Harvard University Press, Cambridge, Massachusetts, USA. p 60.

SMITH, R.L \& E BRIGGS 2015. Using Camera Traps to Determine Group Demographics in a Paraguayan Population of Sapajus Cay. Neotropical Primates 22: 81-88.

WELDON, P.J et al 2003. Benzoquinones from Millipedes Deter Mosquitoes and Elicit Self-Anointing in Capuchin Monkeys (Cebus spp.). Naturwissenschaften 90: 301-304.

YADAVA, R.N \& P TRIPATHI 2000. Chemical Examination and Anti-Inflammatory Action of the Extract from the Stem of Albizia procera. Research Journal of Chemistry and the Environment 4: 57-60.

ZHANG, H 2011 Cytotoxic Oleanane-Type Saponins from Albizia inundata. Journal of Natural Products 74: 477-482.

\author{
Mammalogy Notes | Notas Mastozoológicas \\ Sociedad Colombiana de Mastozoología \\ Vol. 4 Num. 1| 2017
}

